\title{
TOTAL PHENOLIC AND FLAVONOID CONTENT, FREE RADICAL SCAVENGING ACTIVITY AND TYROSINASE INHIBITION OF CORN COB (ZEA MAYS) EXTRACT
}

\author{
INDRI KUSUMA DEWI ${ }^{*}$, SUHENDRIYO1, INDART01, SUWIJIYO PRAMONO², ABDUL ROHMAN², RONNY MARTIEN² \\ ${ }^{1}$ Department of Indonesian Traditional Medicines, Poltekkes Kemenkes Surakarta, Central Java, 57425, Indonesia. ${ }^{2}$ Faculty of Pharmacy, \\ Gadjah Mada University, Yogyakarta, Indonesia.
}

*Email: indri.kusumadewi@gmail.com

Received: 02 Sep 2020, Revised and Accepted: 07 Oct 2020

ABSTRACT

Objective: Corn cob is a part of plant Zea mays that have a phenolic and flavonoid compounds. This research aims to evaluate total phenolic and flavonoid content, free radical scavenging activity and tyrosinase inhibiton of corn cob (Zea mays) extract.

Methods: Corn cob were determined in Poltekkes Kemenkes Surakarta. Meanwhile, corn cob were extracted using maceration method applying 70\% ethanol solvent. This extract were analyzed through the total fenolic and flavonoids content tests apply spectrofotometric UV Vis, antioxidant activity using radical scavenging test 2,2-difenill-1-pikrilhidrazil (DPPH) and tyrosinase inhibition test applying in vitro tyrosinase enzyme inhibition.

Results: Total phenolic content of the corn cob extract were $1.76 \% \mathrm{~b} / \mathrm{b}$ EAG, while the total of flavonoids content were $0.42 \% \mathrm{~b} / \mathrm{b}$ EK. The antioxidant activity using DPPH method test of corn cob extract were values $\mathrm{IC}_{50} 38.57 \mu \mathrm{g} / \mathrm{ml}$. Tyrosinase inhibition of corn cob extract were values $\mathrm{IC}_{50} 919.78 \mu \mathrm{g} / \mathrm{ml}$.

Conclusion: Corn cob extract had antioxidant activity and tyrosinase inhibition.

Keywords: Total phenolic, Total flavonoid, Free radical scavenging, Tyrosinase inhibiton, 2,2-difenill-1-pikrilhidrazil, Corn cob

(C) 2021 The Authors. Published by Innovare Academic Sciences Pvt Ltd. This is an open access article under the CC BY license (http://creativecommons.org/licenses/by/4.0/) DOI: http://dx.doi.org/10.22159/ijap.2021.v13s2.19 Journal homepage: https://innovareacademics.in/journals/index.php/ijap

\section{INTRODUCTION}

Indonesia is an agrarian country which is abundant in the availability of crop resources. Corn is one of the major crop in Indonesia. Based on Statistic Indonesia the corn yields in 2015 valued 19,612,435 tons and has increased 604,009 thousand tons compared to the yields in 2014 [1]. Part of the corn used as food source is its kernels, and the consumption of corn resulted large number of waste of corn cobs Based on data, there is about 13 million tons of corn cob waste which is produced in Indonesia [2]. Meanwhile, the previous result proved that corn cob waste had flavonoids content [3]. Antioxidant is proven to have correlation with flavonoids content [4]. Although corn cob is a waste, yet it is proven to have some benefits in the previous researches. Some of the benefits are as anti-tumor [5], anti-fungus [6], and antioxidant [7]

An antioxidant can inhibit reactive oxygen species (ROS) and/or reactive nitrogen species RNS) as well as free radicals [8]. Antioxidant can be obtained from natural and synthetic sources [9] The synthetic antioxidants included BHA (Butylated Hydroxy Anisole), BHT (Butylated Hydroxy Toluene), PG (Propyl Gallate), and TBHQ (Tertiary Butyl Hydro Quinone). Synthetic antioxidants are more effective, but the recent studies show that some synthetic antioxidants can cause toxic and mutagenic effects [10]. Therefore, it is necessary to perform research on natural antioxidant. The phenolics content in corn cob was reported to have good antioxidants in preventing free radicals $[3,11]$.

Flavonoids compound is reported to have activity as tyrosinase enzyme inhibitor [12]. Skin has melanin, which is black pigments that protect human's skin from excessive Sun's ultraviolet exposure, while tyrosinase is an enzyme which plays an important role in melanin production [13]. Whitening agent works in the melanin production stage with a mechanism to inhibit tyrosinase enzyme maturation or inhibit granule pigment (melanosomes) from melanocytes to keratinocytes around them. Whitening agent mechanism works by controlling exosomes secretion which is secreted from melanocytes [14]. Therefore, phytochemicals compound which can inhibit tyrosinase enzyme as melanin producer is needed.

The antioxidant activity of corn cob fractions has previously reported using DPPH radical scavenging method. The result showed that ethyl acetate fraction has highest DPPH radical savenging, compared to buthanol, ethanol, petroleum ether and water fractions [15]. The previous study also reported that corn cob extracts of $50 \%$ ethanol extract, $80 \%$ methanol extract, 50\% methanol extract, 80\% methanol and ethyl acetate extract exhibted antioxidant activities using DPPH, ABTS (acid 2,2-Azinobis-3-etilbenzatiazolin-6-sulfonat) and FRAP (Ferric reducing-antioxidant power) methods [3]. However, the activities of corn cob extract toward tyrosinase enzyme inhibitor and DPPH assay method have been not reported yet. Therefore, this research was aimed to evaluate the activity of tyrosinase enzyme inhibition and to evaluate antioxidant activity using DPPH method.

\section{MATERIALS AND METHODS}

\section{Material Sample}

Corn cobs are obtained from local farmers in Klaten, Central Java, Indonesia. The plant determination was conducted at the Jamu Department Laboratory, Poltekkes Kemenkes Surakarta, Indonesia with the certificate number was LB.02.06/11.1.1/420/2020.

Other materials used ini this study included 2,2'-diphenyl-1picrylhydrazyl (DPPH, from Sisco Research Laboratories), technical solvent etanol 70\% (Brataco, Indonesia), Kojic Acid (p. a., Tokyo Chemical Industry), Mushroom Tyrosinase (from Sigma-Aldrich), LBeta-3,4-dihydroxyphenyl-alanine (L-DOPA, p. a Sigma-Aldrich), methanol (E. Merck, Darmstat Germany), dymethil sulfoxide (DMSO from Sigma-Aldrich), quercetine (p. a., Sigma-Aldrich), gallate acid (p. a., Sigma-Aldrich), chloroform (p. a., Merck) and Folin-Ciocalteu phenol LP.

\section{Extraction the corn cobs}

The corn cobs then dried to get Simplicia with simplisia quality parameter. Next, the simplisia is changed into powdered form with specific refined degree according to Mesh measurement standard. Corn cob simplisia powder is extracted using 70\% ethanol applying maceration method for $5 \mathrm{~d}$. Every $100 \mathrm{~g}$ of sample is extracted with $1 \mathrm{~L} 70 \%$ ethanol. The liquid extraction result from the maceration is then evaporated using rotary evaporator water bath so that thick extract of corn cob is formed [15]

\section{Total flavonoid determination}

The determination of total flavonoids was performed according to Farmakope Herbal Indonesia [16]. Weigh carefully about $100 \mathrm{mg}$ of 
extract, put into an Erlenmeyer flask, add $25 \mathrm{ml}$ of methanol P, extract for 1 hour with a magnetic stirrer. Filter into a $25 \mathrm{ml}$ flask, add methanol P through the filter to the mark. A-10 mg of gallic acid was put in a $25 \mathrm{ml}$ flask, dissolve with methanol $\mathrm{P}$, add methanol $\mathrm{P}$ to the mark. Make a series of dilution of the pure compound solution with the levels of $100,70,50,30,15$, and $5 \mu \mathrm{g} / \mathrm{ml}$, respectively. For each 1 $\mathrm{ml}$ of the test solution and each series of the pure compound solution into the appropriate container, add $5.0 \mathrm{ml}$ of retail Folin-Ciocalteu LP ( $7.5 \%$ in water). Let stand for $8 \mathrm{~min}$, add $4.0 \mathrm{ml}$ of $1 \% \mathrm{NaOH}$, incubate for 1 hour. Measure the absorption of each solution at a maximum absorption wavelength of approximately $730 \mathrm{~nm}$. Measure the blank in the same way, without adding test solutions. Make a calibration curve. The total phenolic content is stated as gram equivalent gallate acid every $100 \mathrm{~g}$ subfraction dry weight (\% b/b EAG).

\section{Total phenolic determination}

Total phenolic determination in following with Farmakope Herbal Indonesia II edition. Weigh carefully about $50 \mathrm{mg}$ of extract of corncob, put it into an Erlenmeyer flask, add $25 \mathrm{ml}$ ethanol P, extract for 1 hour with a magnetic stirrer. Filter into a $25-\mathrm{mL}$ flask, rinse the filter paper with $70 \%$ LP ethanol and add $70 \%$ LP ethanol to the mark. Weigh carefully about $10 \mathrm{mg}$ of quercetin into a $25 \mathrm{ml}$ volumetric flask, dissolve it and add $\mathrm{P}$ ethanol to the mark. Make a series of dilution of the comparison solution with the levels of 100 , 75,50 and $25 \mu \mathrm{g} / \mathrm{ml}$, respectively. Pipette separately $0.5 \mathrm{ml}$ test solutions and and each series pure solutions into suitable containers, add $1.5 \mathrm{ml}$ of $\mathrm{P}$ ethanol, $0.1 \mathrm{ml}$ of $10 \%$ aluminum chloride $\mathrm{P}, 0.1 \mathrm{ml}$ respectively $1 \mathrm{M}$ sodium acetate and $2.8 \mathrm{ml}$ of water. Shake and let stand for $30 \mathrm{~min}$ at room temperature. Measure the absorption at the maximum absorption wavelength. Measure the blank in the same way, without the addition of aluminum chloride. Make a calibration curve. The total flavonoids content is stated as gram equivalent quercetin every $100 \mathrm{~g}$ subfraction $(\% \mathrm{~b} / \mathrm{b} \mathrm{EK})$.

\section{Antioxidant activity determination}

Antioxidant activity determination using DPPH method [17]. Each 50 $\mu \mathrm{l}$ corn cob extract with varied concentration is added by put into 1.0 $\mathrm{ml}$ of then mixed in the vortex. After $30 \mathrm{~min}$, the researchers can read its absorbance level at $517 \mathrm{~nm}$ wave length. The absorbance level is also done to blank solutions $(50 \mu \mathrm{l}$ of fraction and $4.950 \mathrm{ml}$ of ethanol) and control (1.0 ml of DPPH $0.4 \mathrm{mmol}$ and $4.0 \mathrm{ml}$ of ethanol).

The amount of antioxidant activity is counted using Equation 1:

Percent (\%) antioxidant activity $=\frac{(\text { Abs kontrol-Abs sampel) }}{\text { Abs kontrol }} \times 100 \% \ldots$

\section{Tyrosinase inhibition}

In vitro tyrosinase inhibition test using spectrofotometri UV-Vis. LDOPA exactly weighed $4.96 \mathrm{mg}$, then dissolved with phosphate buffered solution $(\mathrm{pH}=6.8)$ in a volumetric flask until it reached 10 $\mathrm{ml}$ volume. Prevent this solution from light [18]. Tyrosinase exactly weighed $1 \mathrm{mg}$, then dissolved with phosphate buffered solution $(\mathrm{pH}=6.8)$ in a volumetric flask until it reached $10 \mathrm{ml}$ volume. Dissolved tyrosinase has $496 \mathrm{unit} / \mathrm{ml}$ activity. The solution is kept in low temperature $\left(2-8^{\circ} \mathrm{C}\right)[18]$.

$20 \mathrm{mg}$ kojic acid powder is exactly weighed, then dissolved with phosphate buffered solution until it reached $10 \mathrm{ml}$ volume $(2000$ $\mu \mathrm{g} / \mathrm{ml}$ ) in a volumetric flask. Do the dilution process until varied concentration of kojic acid 1500; 1000; $500250 ; 125$ and $62.5 \mu \mathrm{g} / \mathrm{ml}$ are obtained [19]. $20 \mathrm{mg}$ of fraction/extract is exactly weighed, then dissolved with $1 \mathrm{ml}$ of DMSO and fulfilled with $10 \mathrm{ml}(2000 \mu \mathrm{g} / \mathrm{ml})$ of phosphate buffered solution in a volumetric flask. Do the dilution process until varied concentration of kojic acid 1500; 1000; 500 and $500 \mu \mathrm{g} / \mathrm{ml}$ are obtained [19].

Prepare 4 test tubes (A,B,C,D) then pipette $110 \mu$ l solution of L-DOPA $2.5 \mathrm{mmol}$ and $3 \mathrm{ml}$ of phosphate buffered solution $\mathrm{pH} 6.8$ into each tube incubated for $10 \mathrm{~min}$. After being incubated, add to each tube:

Tube A: $0.13 \mathrm{ml}$ of phosphate buffered solution and $70 \mu \mathrm{l}$ of tyrosinase enzyme

Tube B: $0.2 \mathrm{ml}$ of phosphate buffered solution

Tube C: $0.13 \mathrm{ml}$ of sample solution and $70 \mu \mathrm{l}$ tyrosinase enzyme solution

Tube D: 0.1 phosphate buffered solution and 0.1 sample solution

The tubes are incubated for $25 \mathrm{~min}$ and are read their absorbance levels at $475 \mathrm{~nm}$ wave length.

Inhibition percentage of tyrosinase was calculated with Equation 2 below:

$$
\% \text { Inhibisi }=\frac{(A-B)-(C-D)}{(A-B)} \times 100 \%
$$

With A: Absorbance blank solution is negative with enzyme

B: Absorbance blank solution is negative without enzyme

C: Absorbance sample solution with enzyme

D: Absorbance sample solution without enzyme

\section{RESULTS}

\section{Total flavonoid and phenolic content}

Based on the previous researches, it is proven that the compounds which take responsibility for antioxidant activity are phenolic and flavonoids, so the antioxidant activity from natural ingredients correlated with phenolic and flavonoids compounds [20-22]. The result of phenolic and flavonoids content measurement can be seen in table 1.

Table 1: Total phenolic and flavonoids content of corn cob extract

\begin{tabular}{ll}
\hline Content & Concentration \\
\hline Phenolic & $1.76 \% \mathrm{~b} / \mathrm{b}$ EAG \\
Flavonoids & $0.42 \% \mathrm{~b} / \mathrm{b}$ EK \\
\hline
\end{tabular}

Table 1 shows that extract ethanol has phenolic content valued $1.76 \% \mathrm{~b} / \mathrm{b}$ EAG higher than flavonoids content valued $0.42 \%$.

\section{Antioxidant activity}

Quantitative antioxidant activity was performed using UV-Vis spectrophotometer with DPPH method. The DPPH method principle of measurement is based on compound's ability to experience DPPH radical color intensity decrease by counting its absorbance level at 517 $\mathrm{nm}$ wave length [23]. The DPPH color degradation process is directly proportional to the concentration of the test material added [24].

The parameter to interpret that a compound has antioxidant activity ability is the $\mathrm{IC}_{50}$ value, mean is the concentration from a substrate which cause $50 \%$ of DPPH activity [25]. The smaller $\mathrm{IC}_{50}$ value shows that the compound is more active as an antioxidant. The result of the $\mathrm{IC}_{50}$ value antioxidant activity of corn cob fraction is shown in table 2.
The result in table 2 shows that extract ethanol has $\mathrm{IC}_{50}$ value parameter $38.57 \mu \mathrm{g} / \mathrm{ml}$. Meanwhile vitamin $\mathrm{C}$ as positive control have bigger activity antioxidant with $\mathrm{IC}_{50}$ value is $3.55 \mu \mathrm{g} / \mathrm{ml}$. Based on this results so it can be concluded that extract ethanol responsible for antioxidant activity alongside with flavonoids and total phenolic content. Flavonoids compound can reduce free radicals oxidation by donating hydrogen atom so that it can act as antioxidant [26].

\section{Tyrosinase enzyme inhibition}

The purpose of tyrosinase enzyme inhibition testing is to know the ability of corn cob fraction in inhibiting tyrosinase in forming melanin. The enzyme used in this test is mushroom tyrosinase with dengan substrate L-DOPA and kojic acid as positive control. It is 
known that kojic acid is a tyrosinase inhibitor which is clinically used to overcome skin hyperpigmentation [27]. The result of
IC $5_{50}$ corn cob fraction tyrosinase enzyme inhibition can be seen on table 3.

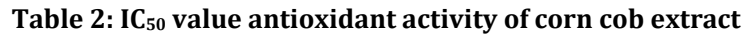

\begin{tabular}{ll}
\hline Sample & $\mathbf{I C}_{\mathbf{5 0}}(\boldsymbol{\mu g} / \mathbf{m l})$ \\
\hline Extract ethanol & $38.57 \pm 13.78$ \\
Vitamin C & $3.55 \pm 0.04$ \\
\hline
\end{tabular}

The data were given in mean+SD; $\mathrm{n}=3$

Table 3: $\mathrm{IC}_{50}$ value tyrosinase enzyme inhibitor corn cob extract

\begin{tabular}{ll}
\hline Sample & $\mathbf{I C}_{50}(\boldsymbol{\mu g} / \mathbf{m l})$ \\
\hline Extract ethanol & 919.78 \\
Kojic acid & 150.79 \\
\hline
\end{tabular}

Table 3 shows the highest activity of inhibiting tyrosinase enzyme is kojic acid as positive control with parameter smallest $\mathrm{IC}_{50}$ value $150.79 \mu \mathrm{g} / \mathrm{ml}$, while extract ethanol has higger value of $\mathrm{IC}_{50}$ is $919.789 \mu \mathrm{g} / \mathrm{ml}$. It is proven that corn cob Extract ethanol also has weak ability in inhibiting tyrosinase enzyme.

Based on reseach tyrosinase inhibitory activity of the ethyl acetate fraction of $C$. fistula leaf that concluded highest polyphenol content, there may have been compounds that interfered with the activity of polyphenols in inhibiting tyrosinase so that the ethyl acetate fraction was less significant at inhibiting tyrosinase [28].

\section{CONCLUSION}

The results of tyrosinase inhibition of corn cob extract is values $\mathrm{IC}_{50}$ $919.78 \mu \mathrm{g} / \mathrm{ml}$. The antioxidant activity using DPPH method test of corn cob extract is values $\mathrm{IC}_{50} 38.57 \mu \mathrm{g} / \mathrm{ml}$. Total phenolic content of the corn cob extract is $1.76 \% \mathrm{~b} / \mathrm{b}$ EAG, while the total of flavonoids content is $0.42 \% \mathrm{~b} / \mathrm{b}$ EK. The conclusion is corn cob extract have antioxidant activity and tyrosinase inhibition.

\section{ACKNOWLEDGMENT}

Appreciation and thanks the author gave to Director Poltekkes Kemenkes Surakarta, Satino, SKM., M. Sc. N. for her guidance this research.

\section{FUNDING}

No competing financial interests exist.

\section{AUTHORS CONTRIBUTIONS}

The author confirms equal responsibility for the following: study conception and design, data collection, analysis and interpretation of results, and manuscript preparation.

\section{CONFLICT OF INTERESTS}

The authors declare that they have no conflicts of interest.

\section{REFERENCES}

1. Badan Pusat Statistik. Data Produksi Jagung di Indonesia. Available from: http://www.bps.go.id/ [Last accessed on 10 Jan 2020].

2. Direktorat Jenderal Tanaman Pangan. Laporan Kinerja Direktorat Jenderal Tanaman Pangan Tahun 2014. Jakarta: Kementerian Pertanian; 2015.

3. Dong J, Cai L, Zhu X, Huang X, Yin T, Fang H. Antioxidant activities and phenolic compounds of cornhusk, corncob and stigma maydis. J Braz Chem Soc 2014;25:1956-64.

4. Fidrianny I, Wulandari E, Hartati R. In vitro antioxidant activity of different organs extracts of corn grown in Cimahi-West JavaIndonesia. Int J Pharmacogn Phytochem Res 2016;8:1025-32.

5. Melo Silveira RF, Viana RLS, Sabry DA, da Silva RA, Machado D, Nascimento AKL, et al. Antiproliferative xylan from corn cobs induces apoptosis in tumor cells. Carbohydrate Polymers 2019;210:245-53.
6. Asadollahi M, Bodi Z, Peles F, Sandor E. Antifungal activity of anthocyanins from purple field corn cob against Botrytis cinerea and Fusarium species. J Agric Sci 2012;50:76-83.

7. Li CY, Kim HW, Li H, Lee DC, Rhee HI. Antioxidative effect of purple corn extracts during storage of mayonnaise. Food Chem 2014;152:592-6.

8. Halliwell B. Reactive species and antioxidants: redox biology is. Plant Phys 2006;141:312-22.

9. Herlina N, Riyanto S, Martono S, Rohman A. Antioxidant activities, phenolic and flavonoid contents of methanolic extract of Stelechocarpus burahol fruit and its fractions. Dhaka Univ J Pharm Sci 2018;17:153-9.

10. Alnajar ZAA, Abdulla MA, Ali HM, Alshawsh MA, Hadi AHA. Acute toxicity evaluation, antibacterial, antioxidant and immunomodulatory effects of Melastoma malabathricum. Molecules 2012;17:3547-59.

11. Lumempouw LI, Suryanto E, Paendong JJE. Aktivitas anti UV-B ekstrak fenolik dari tongkol jagung (Zea mays L). J MIPA UNSRAT 2012;1:1-4.

12. Jegal J, Park SA, Chung KW, Chung HY, Lee J, Jeong EJ, et al. Tyrosinase inhibitory flavonoid from Juniperus communis fruits. Biosci Biotechnol Biochem 2016;80:2311-7.

13. Jin $Y$, Kim JH, Hong H, Kwon J, Lee EJ, Jang M, et al. Ginsenosides Rg5 and Rk1, the skin-whitening agents in black ginseng. J Funct Foods 2018;45:67-74.

14. Bin B, Cho E, Choi E, Kim S, Choi S, Lee T. Skin whitening composition and method for screening for materials having skin whitening effect. Seoul Patent: US2018//0177699A1; 2018.

15. Suryanto E, Irma ML. Isolasi dan aktivitas antioksidan fraksi dari ekstrak tongkol jagung. Agritech 2017;37:139-43.

16. Kemenkes. Farmakope Herbal Indonesia, $2^{\text {nd }}$ edition. Jakarta: Kementerian Kesehatan RI; 2017.

17. Kikuzaki H, Hisamoto M, Hirose K, Akiyama K, Taniguchi H. Antioxidant properties of ferulic acid and its related compounds. J Agric Food Chem 2002;50:2161-8.

18. Arung ET, Kusuma IW, Iskandar YM, Yasutake S, Shimizu K, Kondo R. Screening of Indonesian plants for tyrosinase inhibitory activity. Japan J Wood Sci 2005;51:520-5.

19. Batubara I, Darusman LK, Mitsunaga $T$, Rahminiwati $M_{\text {, }}$ Djauhari E. Potency of Indonesian medicinal plants as tyrosinase inhibitor and antioxidant agent. J Bio Sci 2010;10:138-44.

20. Petrillo A Di, Gonzalez Paramas AM, Era B, Medda R, Pintus F, Santos Buelga $\mathrm{C}$, et al. Tyrosinase inhibition and antioxidant properties of Asphodelus microcarpus extracts. BMC Complement Altern Med 2016;2016:1-9.

21. Rohman A, Riyanto S, Mistriyani, Shuhaira, Nugroho AE. Antiradical activities of rambutan peel: study from two cultivars. Res J Phytochem 2017;411:2-7.

22. Riswahyuli Y, Rohman A, Setyabudi FMCS, Raharjo S. Evaluation of phenolic content and free radical scavenging activity of Indonesia wild honey collected from seven different regions. J Food Res 2019;8:94-103. 
23. Sehwag S, Das M. Antioxidant activity: an overview. Research and reviews: J Food Sci Tech 2013;2:1-10.

24. Masyita A, Yulianty R, Rifai Y. Synthesis and antioxidant evaluation of 3-bromo-flavone. Int J Appl Pharm 2019;11:160-2.

25. Molyneux P. The use of the stable free radical diphenylpicrylhydrazyl (DPPH) for estimating antioxidant activity. Songklanakarin J Sci Technol 2004;2003:211-9.
26. Gupta D. Methods for determination of antioxidant capacity: a review. Intern J Pharm Sci Res 2015;6:546-66.

27. Hashemi SM, Emami S. Kojic acid-derived tyrosinase inhibitors synthesis and bioactivity. Pharm Biomed Res 2015;1:1-17.

28. Wijaya C, Elya B, Yanuar A. Study of tyrosinase inhibitory activity and phytochemical screening of Cassia fistula L. leaves. Int J Appl Pharm 2018;10(Special Issue 1):384-7. 